\title{
An Inhibitor of Sweet Taste Response Modulates Glucose- Induced Phosphoinositide Breakdown in Rat Pancreatic Islets
}

\author{
Keitchiro TANiGAWA, Midori FURUi, Nobumasa HARA*, \\ Masashi SAWADA* AND Yuzuru KATO \\ Departments of Internal Medicine and $*$ Physiology, Shimane \\ Medical University, Izumo 693, Japan
}

\begin{abstract}
We studied the effect of a specific-competitive inhibitor of the sucrose taste response, p-nitrophenyl-D-glucopyranoside (PNP-Glu) on insulin release and phosphoinositide metabolism in rat pancreatic islets. The $\alpha$-anomer, but not the $\beta$-anomer, of PNP-Glu at a concentration of $5 \mathrm{mM}$ inhibited insulin release induced by $10 \mathrm{mM}$ glucose. Islets were labeled by exposure for $2 \mathrm{~h}$ to $10 \mathrm{uCi}$ of myo- $\left[2-{ }^{3} \mathrm{H}\right]$ inositol solution supplemented with $2.8 \mathrm{mM}$ glucose. Forty islets were then incubated in the presence of $10 \mathrm{mM} \mathrm{LiCl}, 1 \mathrm{mM}$ inositol and $10 \mathrm{mM}$ glucose with or without the anomers of PNP-Glu. $\left[{ }^{3} \mathrm{H}\right]$ radioactivity in the incubation medium remained significantly greater in the presence of the $\alpha$-anomer of PNP-Glu than in the presence of glucose alone after 5- and 20-min incubation. The inositol monophosphate levels in the islets incubated with glucose alone were increased more than in the islets with $\alpha$-anomer. The $\beta$-anomer of PNP-Glu did not change either glucose-induced insulin release or phosphoinositide breakdown. A patch-clamp study revealed that neither anomer affected the glucose-dependent ATP-sensitive $\mathrm{K}^{+}$-channels. These results indicate that the anomeric preference for glucose in insulin release in the pancreatic islets is closely associated with phosphoinositide breakdown.
\end{abstract}

Key words: Insulin release, Sweet taste response, Islet, Phosphoinositide breakdown.

(Endocrinol Japon 39: 439-444, 1992)

IT HAS been widely accepted that glucoseinduced insulin release is initiated by glucose metabolism in B-cells and that the ATP-sensitive $\mathrm{K}^{+}$channel plays a role in controlling B-cell function [1-3]. Although phosphoinositide (PI) breakdown may play an important role in the signal-transduction mechanism in pancreatic Bcells $[4,5]$, it remains unclear whether glucose metabolism is directly related to PI breakdown.

Accumulating evidence suggests that common mechanisms are involved in the signal transduction in the sweet taste response of tongue gustatory cells and glucose-induced insulin secretion from pancreatic B-cells [6-8]. Both cells recognize

Received: February 19, 1992

Accepted: June 19, 1992

Correspondence to: Dr. Keiichiro TANIGAWA, First Division, Department of Medicine, Shimane Medical University, 89-1 Enya-cho, Izumo, Shimane 693, Japan. glucose as a physiological stimulant and prefer the $\alpha$-anomer over the $\beta$-anomer of glucose. It is well established that the $\alpha$-anomer of D-glucose causes greater insulin secretion than the $\beta$-anomer of D-glucose from pancreatic islets [9-11].

P-nitrophenyl-D-glucopyranoside (PNP-Glu), a specific-competitive inhibitor of the taste response to sucrose, binds to the glucopyranosyl subsite of the sucrose receptor site with $\alpha$-anomeric preference [12]. Niki et al. recently reported that the $\alpha$-anomer, but not the $\beta$-anomer, of PNP-Glu dose dependently inhibited the release of insulin, induced by $10 \mathrm{mM}$ glucose, from rat pancreatic islets [13], suggesting that PNP-Glu has a possible common mode of chemosensory action in the gustatory cells and the pancreatic B-cells. The taste response can be induced by PI breakdown [14]. In the present study, we examined the effect of anomers of PNP-Glu on glucose-induced PI break- 
down in rat pancreatic islets. We also investigated whether this compound affects the ATP-sensitive $\mathrm{K}^{+}$channel.

\section{Materials and Methods}

By using the collagenase digestion method [15], pancreatic islets were isolated from Wistar strain male rats (Shizuoka Laboratory Center, Hamamatsu, Japan) fed a standard laboratory diet ad libitum. In the first series of experiments, only insulin release was examined. The islets were preincubated for $30 \mathrm{~min}$ in Krebs-Ringer bicarbonate buffer (KRB) containing $2.8 \mathrm{mM}$ glucose and $0.25 \%$ bovine serum albumin (BSA) under $95 \% \mathrm{O}_{2} / 5 \% \mathrm{CO}_{2}$. Each batch of five islets was then incubated for $60 \mathrm{~min}$ at $37^{\circ} \mathrm{C}$ in medium containing various concentrations of glucose, and either the $\alpha$ - or $\beta$-anomer of PNP-Glu at a concentration of $5 \mathrm{mM}$.

In the second series of experiments, islets were labeled with $10 \mathrm{uCi}$ of myo- $\left[2-{ }^{3} \mathrm{H}\right]$ inositol (specific activity, $18.9 \mathrm{Ci} / \mathrm{mmol}, 1 \mathrm{Ci}=37 \mathrm{GBq}$, Amersham, Arlington Heights, IL) in $0.2 \mathrm{ml}$ of $\mathrm{KRB}$ containing 2.8 or $28 \mathrm{mmol}$ of glucose and $0.25 \%$ BSA for $2 \mathrm{~h}$ under $95 \% \mathrm{O}_{2} / 5 \% \mathrm{CO}_{2}$ at $37^{\circ} \mathrm{C}$. The labeled islets were washed five times with $1 \mathrm{ml}$ of $\mathrm{KRB}$ without radioactive inositol. Forty islets were then incubated in the presence of $10 \mathrm{mM}$ glucose, 10 $\mathrm{mM} \mathrm{LiCl}$ and $1 \mathrm{mM}$ inositol. The anomers of PNP-Glu were also added in concentrations of 5 mM. To study the time course of inositol metabolism, incubation was terminated at 0,5 and $20 \mathrm{~min}$ by the addition of $10 \%$ perchloric acid [16] and the inositol phosphates of the islets were separated out by anion exchange chromatography [17]. Samples of the eluate were then counted in a liquid scintillation spectrometer. Insulin levels were measured by radioimmunoassay using rat insulin as a standard [18].

In the third series of experiments, a patchclamp study was performed according to the method described by Misler et al. [3]. Islets were dissociated into single cells or small clusters by pipetting in the medium without $\mathrm{Ca}^{2+}$. The cells were plated on petri dishes and maintained for 3-4 days in $2 \mathrm{ml}$ of the MEM tissue culture medium (Flow Laboratories, Irvine, UK), which was supplemented with $5.6 \mathrm{mM}$ glucose, $10 \%$ heat-inactivated fetal bovine serum (Flow), $100 \mathrm{IU}$ of penicillin per $\mathrm{ml}$ and $100 \mathrm{ug}$ of streptomycin per $\mathrm{m} l$. The bathing solution contained $135 \mathrm{mM}$ $\mathrm{NaCl}, 5 \mathrm{mM} \mathrm{MgSO} \cdot \cdot 7 \mathrm{H}_{2} \mathrm{O}, 5 \mathrm{mM} \mathrm{CaCl}_{2}, 5 \mathrm{mM}$ $\mathrm{KCl}$ and $5 \mathrm{mM}$ HEPES adjusted with $\mathrm{KOH}$ to $\mathrm{pH}$ 7.4. The solution used to fill the patch pipette consisted of $140 \mathrm{mM} \mathrm{KCl}, 1.13 \mathrm{mM} \mathrm{MgCl}_{2}, 0.1$ $\mathrm{mM} \mathrm{CaCl}_{2}$ and $10 \mathrm{mM}$ HEPES adjusted with $\mathrm{KOH}$ to $\mathrm{pH}$ 7.4. The anomers of PNP-Glu, LiCl and inositol were purchased from Sigma Chemical Co. (St. Louis, MO). The ${ }^{125}$ I-labeled insulin was purchased from Dainabot Co. (Tokyo, Japan) and the rat insulin was a gift from Novo (Bagsvaerd, Denmark).

Values represent the mean \pm SEM. Statistical analysis was performed by unpaired Student's $t$-test. For comparing more than three means, Scheffe's method was used. A $P$ value below 0.05 was considered statistically significant.

\section{Results}

The basal release of insulin from pancreatic islets in $2.8 \mathrm{mM}$ glucose was not affected by either the $\alpha$ - or $\beta$-anomer of PNP-Glu at concentrations

Table 1. Effect of the anomers of PNP-Glu on insulin release from rat islets

\begin{tabular}{ccccc}
\hline $\begin{array}{c}\text { Glucose concentration } \\
(\mathrm{mM})\end{array}$ & Control & \multicolumn{2}{c}{$\begin{array}{c}\text { Insulin release } \\
\text { PNP- } \alpha \text {-Glu }\end{array}$} & $\begin{array}{c}\text { (nglet/h) } \\
\text { PNP- } \beta \text {-Glu }\end{array}$ \\
\hline 2.8 & $0.4 \pm 0.0(10)$ & $0.3 \pm 0.0(10)$ & $0.4 \pm 0.1 \quad(10)$ \\
10.0 & $4.9 \pm 0.6(14)$ & $3.8 \pm 0.5(12)^{*}$ & $5.0 \pm 0.5 \quad(12)$ \\
16.7 & $14.6 \pm 3.1 \quad(13)$ & $15.5 \pm 3.4 \quad(7)$ & $12.8 \pm 1.8 \quad(8)$ \\
\hline
\end{tabular}

Islets isolated from rat pancreas were incubated for $30 \mathrm{~min}$ in $\mathrm{KRB}$ containing $2.8 \mathrm{mM}$ glucose. Batches of five islets were then incubated for $1 \mathrm{~h}$ in either the presence or absence of the anomers of PNP-Glu. Mean values $( \pm$ SEM) for insulin release are shown. The numbers of individual observations are indicated in parentheses. ${ }^{*}, P<0.05$ vs. $10 \mathrm{mM}$ glucose alone and plus PNP- $\beta$-Glu. 
of $5 \mathrm{mM}$ (Table 1). Insulin release in response to $10 \mathrm{mM}$ glucose was significantly reduced by the $\alpha$-anomer of PNP-Glu. The $\beta$-anomer of PNP-Glu itself did not affect insulin release caused by 10 $\mathrm{mM}$ glucose. When the glucose concentration in the medium was raised to $16.7 \mathrm{mM}$, insulin release was not affected by the addition of the anomers of PNP-Glu.

The islets were labeled with $\left[{ }^{3} \mathrm{H}\right]$ inositol in the presence of 2.8 or $28.0 \mathrm{mM}$ glucose. When the islets were labeled with $\left[{ }^{3} \mathrm{H}\right]$ inositol in the presence of $28.0 \mathrm{mM}$ glucose, $\left[{ }^{3} \mathrm{H}\right]$ inositol incorporation into the islets was significantly decreased (Table 2).

As shown in Table $3,\left[{ }^{3} \mathrm{H}\right]$ radioactivity in the incubation medium, i.e., $\left[{ }^{3} \mathrm{H}\right]$ efflux, was increased to a greater extent in the islets exposed to the $\alpha$-anomer than in the islets exposed to the $\beta$ -

Table 2. Influence of labeling conditions on tissue partition of $\left[{ }^{3} \mathrm{H}\right]$ inositol in isolated islets

\begin{tabular}{lcrr}
\hline & \multicolumn{3}{c}{$\begin{array}{c}\text { Radioactivity } \\
\text { (cpm/40 islets) }\end{array}$} \\
Labeling condition & W.S. & Islet residue & T.C. \\
\hline $2.8 \mathrm{mM}$ glucose & $8125 \pm 945$ & $11423 \pm 1250$ & $19549 \pm 2111$ \\
$28.0 \mathrm{mM}$ glucose & $2236 \pm 215^{*}$ & $3221 \pm 353^{*}$ & $5537 \pm 509^{*}$ \\
\hline
\end{tabular}

Islets were incubated for $2 \mathrm{~h}$ with $\left[{ }^{3} \mathrm{H}\right]$ inositol in the presence of either 2.8 or $28.0 \mathrm{mM}$ glucose. They were washed five times in the same buffer without radioactive inositol, and then islets were immediately extracted with $\mathrm{HClO}_{4}$. Data represent the mean $( \pm \mathrm{SEM})$ values derived from five separate experiments. W.S., water-soluble product; T.C., total count. ${ }^{*}, P<0.01$ vs. $2.8 \mathrm{mM}$ glucose. anomer or glucose alone. When the incubation period was prolonged to $20 \mathrm{~min},\left[{ }^{3} \mathrm{H}\right]$ efflux further increased in the islets and the difference between the islets incubated with the $\alpha$ - or $\beta$ anomer of PNP-Glu became more apparent. Inositol monophosphate $\left(\mathrm{IP}_{1}\right)$ and inositol bisphosphate $\left(\mathrm{IP}_{2}\right)$ levels were lower in the islets incubated for 20 min in the presence of $\alpha$-anomer than in the presence of $\beta$-anomer or glucose alone. Inositol trisphosphate $\left(\mathrm{IP}_{3}\right)$ was increased at $5 \mathrm{~min}$ and decreased at $20 \mathrm{~min}$, but there was no statistically significant difference among the three groups. The addition of the $\beta$-anomer of PNP-Glu had no significant effect on inositol phosphate levels and insulin secretion compared with $10 \mathrm{mM}$ glucose alone.

The inositol phosphate levels were markedly decreased in the islets labeled in the medium containing $28.0 \mathrm{mM}$ glucose (Table 4 ). In contrast, the mode of action of PNP-Glu was not changed by the concentrations of glucose used in the labeling medium.

Figure 1 illustrates the effect of the $\alpha$-anomer of PNP-Glu on the glucose-sensitive $\mathrm{K}^{+}$channel in cell-attached patches. The addition of $10 \mathrm{mM}$ glucose closed the $\mathrm{K}^{+}$channels within 4-5 min. The $\alpha$-anomer of PNP-Glu did not affect the glucose-induced closure of the $\mathrm{K}^{+}$channel.

\section{Discussion}

The central mechanisms by which glucose

Table 3. Effects of the anomers of PNP-Glu on $\left[{ }^{3} \mathrm{H}\right]$ efflux and $\left[{ }^{3} \mathrm{H}\right]$ inositol phosphate levels

\begin{tabular}{|c|c|c|c|c|c|c|}
\hline \multirow[b]{2}{*}{ Condition } & \multirow[b]{2}{*}{ Time $(\min )$} & \multicolumn{4}{|c|}{ Radioactivity (cpm/40 islets) } & \multirow{2}{*}{$\begin{array}{c}\text { Insulin release } \\
\text { (ng/islet) }\end{array}$} \\
\hline & & Efflux & $\mathrm{IP}_{1}$ & $\mathrm{IP}_{2}$ & $\mathrm{IP}_{3}$ & \\
\hline$t_{0}$ & 0 & 0 & $1453 \pm 177$ & $622 \pm 187$ & $316 \pm 66$ & 0 \\
\hline \multicolumn{7}{|l|}{$10 \mathrm{mM}$ glucose } \\
\hline \multirow[t]{2}{*}{+ None } & 5 & $325 \pm 49$ & $2972 \pm 556$ & $678 \pm 90$ & $404 \pm 58$ & $0.4 \pm 0.1$ \\
\hline & 20 & $980 \pm 89$ & $6556 \pm 981$ & $625 \pm 78$ & $281 \pm 40$ & $1.8 \pm 0.2$ \\
\hline \multirow[t]{2}{*}{+ PNP- $\alpha$-Glu } & 5 & $568 \pm 25^{*}$ & $2054 \pm 276$ & $581 \pm 36$ & $431 \pm 60$ & $0.2 \pm 0.0^{*}$ \\
\hline & 20 & $1318 \pm 68^{*}$ & $4059 \pm 491 *$ & $369 \pm 27$ & $239 \pm 16$ & $1.2 \pm 0.1^{*}$ \\
\hline \multirow[t]{2}{*}{+ PNP- $\beta$-Glu } & 5 & $386 \pm 42$ & $2884 \pm 445$ & $705 \pm 93$ & $458 \pm 47$ & $0.4 \pm 0.0$ \\
\hline & 20 & $977 \pm 74$ & $6387 \pm 794$ & $666 \pm 58$ & $276 \pm 35$ & $1.7 \pm 0.2$ \\
\hline
\end{tabular}

After being labeled for $2 \mathrm{~h}$ with $\left[{ }^{3} \mathrm{H}\right]$ inositol, the islets were washed five times with KRB containing $2.8 \mathrm{mM}$ glucose and the reaction was stopped either immediately $\left(\mathrm{t}_{0}\right)$ or after an additional 5 or $20 \mathrm{~min}$ in either the presence or absence of the anomers of PNP-Glu. Data represent the mean $( \pm$ SEM) values derived from five separate experiments. $\left[{ }^{3} \mathrm{H}\right]$ radioactivity in the incubation medium is defined as efflux. $\mathrm{IP}_{1}$, inositol monophosphate; $\mathrm{IP}_{2}$, inositol bisphosphate; $\mathrm{IP}_{3}$, inositol trisphosphate. ${ }^{*}, P<0.05$ vs. $10 \mathrm{mM}$ glucose alone and plus PNP- $\beta$-Glu. 
Table 4. Effect of the anomers of PNP-Glu on $\left[{ }^{3} \mathrm{H}\right]$ efflux and $\left[{ }^{3} \mathrm{H}\right]$ inositol phosphate levels from islets labeled in $28.0 \mathrm{mM}$ glucose

\begin{tabular}{lccccc}
\hline & \multicolumn{5}{c}{ Radioactivity (cpm/40 islets) } \\
Condition & Time $(\mathrm{min})$ & Efflux & IP $_{1}$ & IP $_{2}$ & IP $_{3}$ \\
\hline $\mathrm{t}_{0}$ & 0 & 0 & $384 \pm 53$ & $232 \pm 41$ & $167 \pm 13$ \\
$10 \mathrm{mM}$ glucose & & & & & \\
$\quad$ + PNP- $\alpha$-Glu & 5 & $256 \pm 42$ & $356 \pm 60$ & $189 \pm 11^{*}$ & $141 \pm 19$ \\
& 20 & $545 \pm 125$ & $994 \pm 61^{*}$ & $219 \pm 36$ & $170 \pm 25$ \\
& 5 & $203 \pm 18$ & $308 \pm 45$ & $123 \pm 12$ & $115 \pm 3$ \\
& 20 & $381 \pm 39$ & $1394 \pm 43$ & $235 \pm 18$ & $140 \pm 20$ \\
\hline
\end{tabular}

Islets were incubated for $2 \mathrm{~h}$ with $\left[{ }^{3} \mathrm{H}\right]$ inositol in the presence of $28.0 \mathrm{mM}$ glucose. They were washed five times in the same buffer without radioactive inositol. The reaction was stopped either immediately or after an additional 5 or $20 \mathrm{~min}$ in the presence of $10 \mathrm{mM}$ glucose and the anomers of PNP-Glu. Data represent the mean $( \pm \mathrm{SE})$ values derived from four separate experiments.

$*, P<0.05$ vs. PNP- $\beta$-Glu.

A

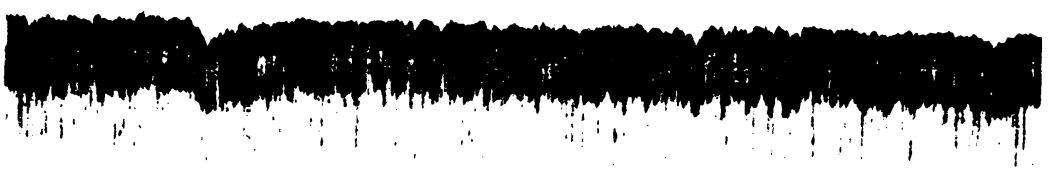

B
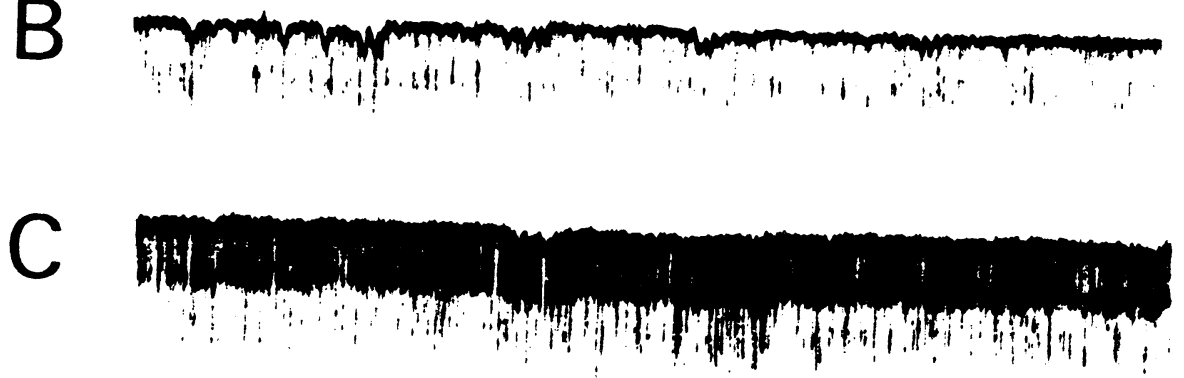

D

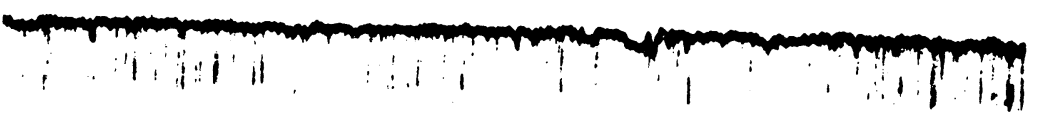

E

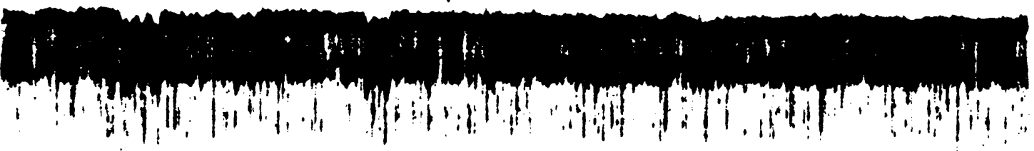

$10 \mathrm{pA}$

\section{$20 \mathrm{sec}$}

Fig. 1. Effect of the $\alpha$-anomer of PNP-Glu on glucose-dependent $\mathrm{K}^{+}$channels in the B-cell. A: channel activity recorded from a cell-attached patch at a pipette potential $(\mathrm{Vp})$ of $+40 \mathrm{mV}$ in the absence of glucose. B: Continuation of the record $7 \mathrm{~min}$ after adding $10 \mathrm{mM}$ glucose. C: $10 \mathrm{~min}$ after washing with buffer alone. D: $7 \mathrm{~min}$ after adding $10 \mathrm{mM}$ glucose plus $5 \mathrm{mM} \alpha$-anomer of PNP-Glu. E: $10 \mathrm{~min}$ after washing with buffer alone. 
stimulates insulin release still remain to be elucidated. The initial and key event in insulin release from pancreatic B-cells appears to be coupled with PI breakdown [4, 5]. Previous studies [19, 20] demonstrated that glucose failed to cause PI breakdown in permeabilized rat islets. However, Wolf et al. [21] found that glucose per se activated phospholipase $\mathrm{C}$ independently from glucose metabolism in permeabilized rat islets, providing direct evidence for the presence of a glucoreceptor in pancreatic B-cells. Although there are clear differences between those studies, the present study may provide additional support for the latter case.

The release of insulin evoked by $10 \mathrm{mM}$ glucose was inhibited significantly by the $\alpha$-anomer of PNP-Glu. This phenomenon does not result from the inhibition of glucose oxidation in the B-cells [10], indicating that glucose transport and glycolysis are not grossly impaired by PNP- $\alpha$-Glu. It is noted that the anomers of PNP-Glu did not affect insulin release induced by basal and maximal concentrations of glucose. Thus, the inhibitory effect of the $\alpha$-anomer of PNP-Glu on insulin release might not be due to toxic and nonspecific actions, and the effect was overcome when the glucose concentration was raised to the maximum.

To examine the possibility that the anomers of PNP-Glu interfere with glucose metabolism, we performed a patch-clamp study using a single B-cell. It has been suggested that the ATPsensitive $\mathrm{K}^{+}$channel is dependent on the status of glucose metabolism, since the addition of mannoheptulose, an inhibitor of hexokinase, reopened $\mathrm{K}^{+}$channels closed down by glucose [1,3]. Our finding that the $\alpha$-anomer of PNP-Glu did not affect $\mathrm{K}^{+}$-channel activities suggests that the inhibition of glucose-induced insulin secretion by the $\alpha$-anomer of PNP-Glu is independent of glucose metabolism and the subsequent ATP production in the pancreatic B-cells.

Since $\mathrm{Li}^{+}$inhibits the dephosphorylation of several inositol phosphates generated during stimulated PI breakdown, $\mathrm{LiCl}$ is often used to increase the sensitivity of detecting inositol cycling in pancreatic islets $[19,20,22]$ as well as other tissues [17]. One can expect an increase in $\mathrm{IP}_{1}$ levels and a decrease in $\left[{ }^{3} \mathrm{H}\right]$ efflux in the presence of LiCl. However, when the $\alpha$-anomer of PNP-Glu was present in the incubation medium, $\mathrm{IP}_{1}$ levels were unexpectedly lower than in the presence of glucose alone or the $\beta$-anomer of PNP-Glu. On the other hand, $\left[{ }^{3} \mathrm{H}\right]$ efflux was markedly higher in the presence of the $\alpha$-anomer than glucose alone or the $\beta$-anomer. These results strongly suggest that the $\alpha$-anomer of PNP-Glu interferes with PI breakdown caused by glucose.

Rana et al. [23] reported that there are glucoseresponsive and -unresponsive phospholipid pools in rat pancreatic islets. As shown in Table 2, high concentrations of glucose in the labeling medium somewhat inhibited the incorporation of $\left[{ }^{3} \mathrm{H}\right]$ inositol into the islet-inositol pool. This finding is consistent with the previous observation by Zawalich et al. [24]. Thus, when islets are labeled with radioactive inositol, high concentrations of glucose should not be used. However, even in such conditions, the data on PI breakdown yielded by the present study are quite comparable. Although our study did not establish a direct link between the action of PNP-Glu and PI breakdown, the present data suggest that anomeric preference of glucose in insulin release is closely associated with PI metabolism in pancreatic B-cells.

\section{Acknowledgments}

We are grateful to Professor A. Niki for his helpful discussion and encouragement throughout this work. We are also indebted to Dr. J. H. Byrne for critical reading of the manuscript. We acknowledge the skilled technical assistance of $\mathrm{Y}$. Hara and the secretarial assistance of A. Kawakami.

A part of this study was presented at the satellite conference "pancreatic $\beta$-cell 1991: gene to disease" to the 14th IDF, June, 1991. 


\section{References}

1. Ashcroft FM, Harrison DE, Ashcroft SJH (1984) Glucose induces closure of single pottasium channels in isolated rat pancreatic $\beta$-cells. Nature 312 : 446-448.

2. Rorsman P, Trube G (1985) Glucose dependent $\mathrm{K}^{+}$-channels in pancreatic $\beta$-cells are regulated by intracellular ATP. Rflugers Arch 405: 305-309.

3. Misler S, Falke LC, Gillis K, McDaniel ML (1986) A metabolite-regulated potassium channel in rat pancreatic B cells. Proc Natl Acad Sci USA 83: 7117-7123.

4. Prentki M, Matschinsky FM (1987) $\mathrm{Ca}^{2+}$, cAMP, and phospholipid-derived messengers in coupling mechanisms of insulin secretion. Physiol Rev 67: 1185-1284

5. Zawalich WS and Rasmussen H (1990) Control of insulin secretion: a model involving $\mathrm{Ca}^{2+}$, cAMP and diacylglycerol. Mol Cell Endocrinol 70: 119-137.

6. Kinnamon SC (1988) Taste transduction: a diversity of mechanisms. Trends Neurosci 11: 491-496.

7. Teeter J, Gold GH (1988) A taste of things to come. Nature 331: 298-299.

8. Niki A, Niki H, Hashioka T (1989) Receptors of paraneurons, with special reference to glucoreceptors. Arch Histol Cytol 52: 33-38.

9. Niki A, Niki H, Miwa I, Okuda J (1974) Insulin secretion by anomers of D-glucose. Science 186: $150-151$.

10. Grodsky GM, Fanska R, West L, Manning M (1974) Anomeric specificity of glucose-stimulated insulin release: Evidence for a glucoreceptor? Science 186: 536-538.

11. Grodsky GM, Fanska R, Lundquist I (1975) Interrelationships between $\alpha$ and $\beta$ anomers of glucose affecting both insulin and glucagon secretion in the perfused rat pancreas. Endocrinology 97: $573-580$.

12. Jakinovich W Jr, Sugarman D (1988) Sugar taste reception in mammals. Chemical Senses 13: $337-342$.

13. Niki A, Niki H, Hashioka T (1989) An inhibitor of sweet taste response inhibits glucose-induced insulin release. Biomed Res 10: 169-172.

14. Hwang PM, Verma A, Bredt DS, Snyder SH (1990) Localization of phosphatidylinositol signaling com- ponents in rat taste cells: role in bitter taste transduction. Proc Natl Acad Sci USA 87: 7395-7399.

15. Lacy PE, Kostianovsky M (1967) Method for the isolation of intact islets of Langerhans from the rat pancreas. Diabetes 16: 35-39.

16. Zawalich WS, Zawalich KC (1988) Phosphoinositide hydrolysis and insulin release from isolated perifused rat islets: studies with glucose. Diabetes 37: 1294-1300.

17. Berridge MJ, Dawson RMC, Downs CP, Heslop JP, Irvine FF (1983) Changes in the levels of inositol phosphates after agonist-dependent hydrolysis of membrane phosphoinositides. Biochem $J$ 212: 473-482.

18. Desbuquois S, Auerbach GD (1971) Use of polyethylene glycol to separate free and antibodybound hormones in radioimmunoassay. J Clin Endocrinol 33: 732-738.

19. Best L (1986) A role for calcium in the breakdown of inositol phospholipids in intact and digitoninpermeabilized pancreatic islets. Biochem $J$ 238: 773-779.

20. Yamaguchi T, Kanatsuka A, Makino H, Ohsawa $\mathrm{H}$, Yoshida S (1989) Dual mechanism involved in the hydrolysis of polyphosphoinositides in rat islets. Endorinology 124: 1870-1874.

21. Wolf BA, Florholmen J, Turk J, McDaniel ML (1988) Studies of the $\mathrm{Ca}^{2+}$ requirements for glucose- and carbachol-induced augmentation of inositol trisphosphate and inositol tetrakisphosphate accumulation in digitonin-permeabilized islets. J Biol Chem 263: 3565-3575.

22. Tanigawa K, Lewis NJ, Freinkel N (1991) Inositol cycling and phosphoinositide metabolism in rat pancreatic islets. Endorinol Japon 38: 23-31.

23. Rana RS, Mertz RJ, Kowluru A, Dixon JF, Hokin LE, Macdonald MJ (1985) Evidence for glucoseresponsive and -unresponsive pools of phospholipid in pancreatic islets. $J$ Biol Chem 260: 7861-7867.

24. Zawalich WS, Zawalich KC, Rasmussen H (1989) The conditions under which rat islets are labelled with $\left[{ }^{3} \mathrm{H}\right]$ inositol after the subsequent responses of these islets to a high glucose concentration. Biochem J 259: 743-749. 